\title{
Ivan Cerovac*, Maša Dunatov***
}

\section{Liberalni odgovori na problem uskraćivanja zdravstvene skrbi djeci i maloljetnicima iz religijskih razloga ${ }^{1}$}

\begin{abstract}
SAŽETAK
Medicinska praksa u Hrvatskoj i svijetu sve češće svjedoči slučajevima u kojima roditelji, na osnovi religijskih razloga, odbijaju djetetu pružiti potrebnu medicinsku skrb ili se pak protive određenim medicinskim tretmanima nužnim za očuvanje zdravlja (a ponekad i života) djeteta. Roditelji su u ovim slučajevima uvjereni da djeluju u dobroj namjeri i u korist djeteta, što dovodi do problema s pravnom regulacijom ovakvih praksi, odnosno do nesuglasica vezanih uz prava roditelja i djece, kao i uz opravdanost državnih intervencija u ovoj sferi. U radu pružamo pregled četiriju mogućih liberalnih odgovora na postavljeni problem (liberalni arhipelag, liberalni multikulturalizam, egalitarni liberalizam i liberalni feminizam), specificiramo ovlasti državne intervencije koje ove teorije pretpostavljaju te pružamo pregled njihovih glavnih prednosti, kao i kritika koje im se upućuju.
\end{abstract}

Ključne riječi: multikulturalizam, liberalni arhipelag, liberalni feminizam, egalitarni liberalizam

Prostor preklapanja religije i zdravlja predstavlja vrlo široko i plodonosno područje za bioetička istraživanja; štoviše, iznimno je zahvalno za primjenu interdisciplinarnog pristupa (uključuje znanosti i discipline poput teologije, filozofije, etike, antropologije, psihologije, kulturologije, sociologije i medicine, ali i druge), čija se važnost naglašava

\footnotetext{
* Filozofski fakultet Sveučilišsta u Rijeci.

*** Medicinski fakultet Sveučilišta u Rijeci.

Adresa za korespondenciju: Ivan Cerovac, Odsjek za filozofiju, Filozofski fakultet Sveučilišta u Rijeci, Sveučilišna avenija 4, 51000 Rijeka, Hrvatska. E-pošta: icerovac@ffri.hr.

1 Rad je izrađen u sklopu projekta 'Dobrobit, pripadnost i društvena pravednost' (UIP-2017-05-3462) koji je sufinancirala Hrvatska zaklada za znanost.
} 
i u Riječkoj deklaraciji o budućnosti bioetike (Jurić 2011). Bioetika svoj poseban status može, između ostalog, zahvaliti činjenici da je istovremeno i normativna i deskriptivna disciplina; ona se istovremeno bavi proučavanjem toga kako stvari jesu (medicina, sociologija, psihologija) i kako bi stvari trebale biti (teologija, filozofija, etika). U ovom se očituje njen integrativni karakter i težnja da se normativne teze primijene na stvarne praktične probleme i da postignuti rezultati unaprijede naše znanje, ali i društvo u kojem živimo ${ }^{3}$.

Među slučajevima sukoba između nekih religijskih vrijednosti, normi i običaja s jedne, te standarda, praksi i normativnih načela suvremene medicine u liberalnom društvu s druge strane, posebno mjesto uzimaju pitanja uskraćivanja medicinskog tretmana djeci i osobama koje nisu u mogućnosti samostalno donositi odluke od strane njihovih roditelja ili staratelja, a sve na osnovi razloga utemeljenih u religijskim vrijednostima, normama i običajima. Primjerice, roditelji koji se izjašnjavaju kao sljedbenici kršćanske znanosti, modernog alternativnog duhovnog pokreta, smatraju da se sve bolesti mogu liječiti molitvom te odbijaju mogućnost da im djeca koja boluju od teških bolesti budu liječena metodama suvremene medicine. Jehovini svjedoci prihvaćaju veći dio metoda suvremene medicine, međutim, iz religijskih se razloga protive transfuziji krvi i često odbijaju mogućnost da njihova djeca prime transfuziju krvi, čak i kada bi ona značajno pomogla u liječenju. Različiti liberalni odgovori na sukob vrijednosti koji proizlazi iz slobode vjeroispovijesti i slobode da se vlastitu djecu odgaja u skladu s religijskim vrijednostima $s$ jedne, te prava djece na adekvatnu medicinsku skrb i kvalitetan život s druge strane, u središnjem su fokusu ovog rada.

Ovaj se rad neće usredotočiti na deskriptivne elemente problema koje obrađuje (neće se detaljno opisivati različite religijske prakse vezane uz zdravlje ili utjecaj religioznosti na zdravlje vjernika, pogotovo $s$ naglaskom na slučajeve roditeljskog uskraćivanja medicinske skrbi djeci na osnovi religijskih razloga), već će se u središte postaviti normativna razmatranja o modelima uređenja zajednice i pravnog sustava u uvjetima religijskog i moralnog pluralizma. Zbog toga će se ovoj temi pristupiti prvenstveno iz područja etike i političke filozofije, iako će se poseban naglasak ostaviti na činjenici da i druge discipline moraju dati svoj doprinos, odnosno na ideji da normativne znanosti ne mogu donositi ispravne sudove bez da se povežu i surađuju s deskriptivnim prirodnim i društvenim znanostima.

\footnotetext{
2 Točka 2. Bioetiku treba bitno proširiti te konceptualno i metodološki transformirati kako bi bila u stanju sagledavati različite kulturne, znanstvene, filozofske i etičke perspektive (pluriperspektivni pristup), integrirajucí ih u orijentacijsko znanje i praktičnu akciju (integrativni pristup) (Jurić 2011).

3 Točka 7. Ako ove ideje zažive, bioetika će postati osnova za razvoj $i$ implementaciju zakona na nacionalnoj $i$ medunarodnoj razini (Jurić 2011).
} 
Također, ovaj rad ne obrađuje sve slučajeve u kojima roditelji ne pružaju djeci adekvatnu medicinsku njegu. Slučajevi u kojima roditelji odbijaju da njihovo dijete primi neki medicinski tretman zbog nemara ili nedostatka brige za dijete nisu obrađivani, kao ni slučajevi roditelja koji imaju dobre namjere prema djetetu, ali nemaju potrebno znanje ili su krivo informirani (primjerice slučajevi u kojima roditelji odbijaju cijepljenje djece, ne zato jer im nije stalo do djetetova zdravlja, nego upravo zato jer im je stalo do djetetovog zdravlja, no raspolažu pogrešnim informacijama). Rad se bavi samo slučajevima u kojima je roditeljima stalo do djetetova blagostanja, nisu krivo informirani (ispravno vjeruju da je određeni medicinski tretman učinkovit), ali ga odbijaju primijeniti iz religijskih razloga.

Ovaj rad možemo ugrubo podijeliti u četiri cjeline: u prvoj prikazujemo osnovne značajke odnosa zdravlja i religije te ukazujemo na niz problema koji nastaju u društvu koje karakterizira pluralizam religijskih, moralnih i vrijednosnih doktrina. Bioetika može značajno pridonijeti rješavanju problema ove vrste, budući da zagovara i omogućava dijalog između različitih znanstvenih disciplina, te zastupnika različitih religijskih ili moralnih svjetonazora. $\mathrm{U}$ drugom dijelu iznosimo središnje pitanje kojim se ovaj rad bavi: imaju li, i do koje razine, roditelji pravo da na osnovi vlastitih religijskih uvjerenja uskrate svojoj djeci zdravstvenu zaštitu ili pomoć koja bi im inače mogla biti dostupna. Prikazujemo nekoliko primjera u kojima roditelji, na osnovi religijskih razloga, odbijaju djeci pružiti adekvatne medicinske tretmane koji bi mogli značajno pridonijeti njihovu zdravlju ili im čak sačuvati život. Bitno je još jednom naglasiti kako je ovaj rad usredotočen upravo na slučajeve odbijanja medicinskih tretmana zbog religijskih razloga - u njemu ne razmatramo razloge utemeljene u pogrešnim ili znanstveno neprovjerenim informacijama, kao ni slučajeve nebrige ili zapostavljanja djece, odnosno nepružanja adekvatne medicinske skrbi zbog zapostavljanja. Središnje se pitanje može i preformulirati: koje su dužnosti liberalne države i do koje se mjere ona smije uplitati u privatnu sferu pojedinaca, odnosno smije li uopće otvoreno promicati određeni ideal dobrog života (liberalna neutralnost države) s ciljem zaštite ili promicanja dobrobiti djece. Možemo li intervenciju države s ciljem zaštite zdravlja djece smatrati kršenjem liberalnog kriterija neutralnosti (Rawls 1971)? U trećem dijelu prikazat ćemo i evaluirati niz odgovora na ova pitanja prisutnih u liberalnoj filozofskoj tradiciji; doseg ovih (liberalnih) teorija iznimno je širok, tako da će se ovdje naći i pozicije koje smatraju da se država nema nikakvo pravo uplitati u privatne stvari pojedinaca, čak i kad religijske prakse određene grupe štete dotičnoj djeci - liberalni arhipelag (Kukathas 2003), kao i one koje smatraju da su roditelji pak ti koji nemaju nikakva prava nad vlastitom djecom, već im se samo može dodijeliti privilegija da ih odgajaju, i to samo dok su njihove odluke u skladu s interesima djeteta - liberalni feminizam (Okin 1989). Između ovih dviju dijametralno suprotnih pozicija nalazi se čitav niz drugih, umjerenijih teorija, od kojih smo izdvojili dvije 
najutjecajnije: egalitarni liberalizam (Barry 2001) koji čvrsto nastupa tvrdeći kako je dužnost (liberalne) države štititi sve njezine građanine, pa tako i djecu religioznih roditelja koji, iz religijskih ili nekih drugih razloga, ne žele da njihova djeca dobiju određene medicinske tretmane koji bi im mogli poboljšati zdravlje ili čak spasiti život, te liberalni multikulturalizam (Kymlicka 1995), prema kojem se nacionalnim i kulturnim (pa tako i religijskim) manjinama trebaju dodijeliti posebna manjinska prava (Kymlicka misli prvenstveno na prava u pozitivnom smislu, tj. da država ima obavezu pomagati različitost i opstojanje različitih kulturnih praksi, zakonodavno i financijski), no ipak im se ne smije tolerirati teško kršenje ljudskih prava. U četvrtom dijelu pružamo osnovnu evaluaciju ovih pozicija i naznake usmjeravanja i kretanja daljnje rasprave.

\section{Razložni pluralizam, religija i zdravlje}

John Rawls (1971, 1993) religije opisuje kao sveobuhvatne doktrine, one koje pokrivaju stavove o tome što je vrijedan život i koji su ispravni i neispravni obrasci ponašanja i djelovanja. Budući da je zdravlje usko vezano uz mogućnost realizacije vrijednog životá, religije su često čvrsto povezane sa zdravljem.

Ovaj odnos možemo vidjeti i iz niza slučajeva u kojima su običaji i prakse različitih religija u osnovi povezani (i opravdani) s težnjom očuvanja zdravlja. Zabranu jedenja svinjskog mesa u islamu tako možemo objasniti činjenicom da se takvo meso brzo kvari, pogotovo pri temperaturama i u klimi karakterističnoj za područja gdje je islam nastao i gdje se prvih nekoliko stoljeća razvijao. Na sličan način možemo objasniti i židovsku praksu obrezivanja, koja se s obzirom na pješčano područje na kojem je ta religija nastala, te na higijenske uvjete koji su tada vladali, može opravdati kao sredstvo očuvanja zdravlja vjernika. U ovoj religiji također nalazimo (p)opis životinja koje se smiju, odnosno onih koje se ne smiju jesti, koji na za to vrijeme adekvatan način odvaja jestive od nejestivih, odnosno otrovnih životinja. Kod Židova su, kao i kod muslimana, prisutna i obavezna (obredna) pranja prije jela ili molitve, te nakon čitavog niza aktivnosti, među kojima su doticaj s mrtvim tijelom, jelo, san, dodirivanje inače odjećom prekrivenih dijelova tijela, krvarenje i slično. Jasno je kako su ove religijske prakse korisno utjecale na higijenu, a time i na zdravlje pripadnika ovih vjerskih zajednica. Za kraj možemo još navesti primjer incesta koji je strogo zabranjen u većini svjetskih religija, $s$ jasnim ciljem zaštite zdravlja budućeg potomstva (Škrobonja, Muzur i Rotschild 2003).

4 Rawls zdravlje navodi kao jedno od prirodnih primarnih dobara, onih potrebnih za realizaciju bilo koje koncepcije dobrog života (Rawls 1971). 
Ovo, međutim, nije jedina poveznica religije i zdravlja; nama će biti daleko zanimljivije proučiti odnos religije i medicine, znanosti koja se bavi dijagnosticiranjem, liječenjem i prevencijom bolesti. Ovo će se pokazati kao izrazito plodonosno područje za bioetička istraživanja, no zbog ograničenog opsega ovog rada nećemo ulaziti u takve teme već ćemo se orijentirati na probleme s kojima se medicina suočava u modernom društvu okarakteriziranom kulturnim, religijskim i moralnim pluralizmom.

\section{Medicina u uvjetima religijskog i moralnog pluralizma}

U svim modernim liberalnim i demokratskim društvima prisutan je razložni pluralizam $^{5}$ vrijednosnih i moralnih doktrina; to nas ne treba čuditi, budući da će, kad su zajamčene slobode govora i udruživanja, te država ne promiče određenu koncepciju dobra, nužno doći do različitih razmišljanja i svjetonazora, te vjerskih, političkih ili moralnih udruženja i organizacija (Talisse 2009a). Također će različiti građani različite moralne ili religijske stavove smatrati temeljnima i fundamentalnima, te se, budući da zastupaju različite moralne stavove, građani neće slagati oko temeljnih pitanja. Veoma često ovo razložno neslaganje nastaje upravo na temama kojima se bioetika intenzivno bavi; dvije ili više grupa ljudi drži nekompatibilne i suprotstavljene, ali (barem minimalno) plauzibilne i razložne teze, a vrijednosti koje u njima zastupaju toliko su im važne da ne mogu prihvatiti kompromis ili prepustiti odluku preferencijama ili stavovima većine.

Primjer ovakvog neslaganja može biti pitanje pobačaja; i zastupnici i protivnici prava na pobačaj mogu imati dobre argumente i razloge na osnovi kojih brane svoju poziciju, i čini se da (zato što im te vrijednosti tako puno znače) niti jedni ni drugi nemaju razloga pokoriti se konačnoj demokratski donesenoj odluci, niti pristati na proizvoljni kompromis. Protivnici prava na pobačaj tako će ovu situaciju usporediti sa stanjem u nacističkoj Njemačkoj; bilo bi apsurdno tvrditi da Nijemac koji smatra da je ubijanje Židova pogrešno ipak mora sudjelovati u tim zločinima zato jer ih većina podržava. To što je država donijela zakone za istrebljenje Židova nije razlog da im se pokoravamo, pogotovo kad je toliko jasno da su oni moralno neprihvatljivi. $\mathrm{Na}$ sličan način protivnici prava na pobačaj mogu tvrditi kako činjenica da je država donijela zakone koji legaliziraju pobačaj nije nikakav razlog da im se pokoravaju, budući da su sigurni da se radi o nečem moralno pogrešnom. Otpor i blokiranje

5 Ovakav pluralizam treba jasno razlikovati od vrijednosnog skepticizma ili relativizma; on označava čisto deskriptivnu tezu kako postoji više razložno prihvatljivih moralnih doktrina. Razložni pluralizam ne govori ništa o istinitosti samih doktrina, pa se time ne izjašnjava ni oko pitanja je li samo jedna doktrina istinita ili je moguće da postoji više istinitih doktrina. Isto tako, razložni pluralizam se treba razlikovati od multikulturalizma, budući da ne tvrdi da je postojanje različitosti, odnosno postojanje više suprotstavljenih doktrina, moralno dobro ili korisno. Razložni je pluralizam i po ovom pogledu deskriptivan - različitost nije moralno dobra niti moralno loša, ona je činjenica suvremenih demokratskih društava (Rawls 1993) 
klinika u kojima se pobačaji vrše mogu smatrati sasvim opravdanim, iako je riječ o protivljenju odlukama koje su donesene procedurom većinskog odlučivanja. Slično se mogu postaviti i primjeri s eutanazijom, ženskim genitalnim sakaćenjem, afirmativnom akcijom ili homoseksualnim brakovima ${ }^{6}$.

Kao što smo vidjeli, sukobi između međusobno nekompatibilnih, ali razložnih pozicija vrlo su česti u područjima preklapanja religije i zdravlja, te je veoma teško na njih adekvatno odgovoriti. Svaki religijski ili moralni svjetonazor određena ponašanja ili radnje nikako ne može tolerirati, a za dosta njih postoji suprotan, ali također plauzibilan svjetonazor koji ne može tolerirati zabranu takvih ponašanja ili radnji (Talisse 2009b).

U ostatku ovog rada prikazat ćemo jedan sličan primjer: prvi će svjetonazor tako smatrati da roditelji imaju pravo (iz religijskih razloga) uskratiti vlastitom djetetu određeni medicinski tretman, dok će drugi tvrditi kako država treba štititi pravo djeteta na život i uskratiti roditeljima pravo da odbijanjem medicinskog tretmana ugrožavaju interese, zdravlje i život djeteta ${ }^{7}$.

\section{Problem: Roditelji koji iz religijskih razloga odbijaju liječenje svoje djece}

Većina religija molitvu preporučuje kao dodatak regularnoj zdravstvenoj njezi; neke, međutim, idu dalje i podučavaju kako određene medicinske procedure nisu dozvoljene ili, pak, tvrde kako bi vjernici općenito trebali odbaciti zdravstvenu njegu i okrenuti se isključivo molitvi. Iako postoji čitav niz manjih sekti koje usvajaju jedno od ovih učenja, zanimljivije je promatrati primjere iz dviju nešto afirmiranijih vjerskih skupina: Kršćanske znanosti i Jehovinih svjedoka (Ontario Consultants on Religious Tolerance 2005).

6 Za detaljniju razradu primjera ovih sukoba temeljnih moralnih vrijednosti vidi knjigu Democracy and Moral Conflict Roberta Talissea.

7 Razložni pluralizam označava postojanje većeg broja razložnih koncepcija dobrog života. Što čini neku koncepciju dobra razložnom, međutim, često nije jasno definirano. Najčešći je odgovor kako je koncepcija dobra razložna kada je prihvaćaju razložni građani. Ovim smo problem samo pomakli na drugu razinu, budući da se sada možemo pitati kada su građani razložni? Kod Rawlsa (1993) razložnost je moralna kvalifikacija, a građani su razložni kada ne nastupaju tiranijski provodeći svoju koncepciju dobra već kad su spremni drugim razložnim građanima ponuditi pravične uvjete kooperacije, gledajući na njih kao na slobodne i jednake. Kod Talissea (2009a) razložnost je epistemička kvalifikacija, a građani su razložni kada su spremni ponuditi razloge za svoje tvrdnje i razmotriti kritike koje im drugi upućuju. U ovom radu polazimo od Rawlsovog shvaćanja razložnog pluralizma. Prema tome, da bi koncepcija dobra bila razložna, ona ne treba biti utemeljena u epistemički dobrim razlozima (iako treba ispuniti neke epistemički minimalne standarde, poput unutarnje konzistentnosti), već treba zadovoljiti određene moralne standarde, poput prihvaćanja ideje da se politička moć nad drugim razložnim građanima može vršiti samo uz njihov pristanak. Neke religije tako mogu biti okarakterizirane kao razložne koncepcije dobra, iako njihove tvrdnje nisu poduprte epistemički valjanim ili čvrstim razlozima. 
Prije nego što ukratko sagledamo nekoliko slučajeva u kojima su roditelji, članovi ovih religijskih zajednica, uskratili svojoj djeci dostupnu medicinsku njegu, trebamo pogledati predstavljaju li možda ove religije problem ne samo za djecu, već i za odrasle osobe. Neki bi snažni paternalisti mogli smatrati kako je dužnost države da zabrani ovakva religijska udruženja, budući da promiču za ljudsko zdravlje štetna vjerovanja. Budući da je zadatak države da štiti interese pojedinaca, ona bi trebala zabraniti religijska udruženja čija učenja štete ljudskom zdravlju. Ovo je, međutim, jako zahtjevna teza koju će malo koji liberal biti spreman prihvatiti - većina će prihvatiti tezu blagog paternalizma prema kojoj se država ne smije uplitati u privatnu sferu i ograničavati autonomiju pojedinaca dok god ovaj ne šteti drugima oko sebe, te dok slobodno, svjesno i informirano donosi za sebe štetne odluke. U slučaju odrasle osobe koja slobodno, svjesno i informirano prihvaća određeni religijski ili moralni svjetonazor, ma koliko on bio štetan za tu osobu, država ne smije intervenirati zabranom i prisilom, već samo i isključivo savjetodavno (Mill 1963).

Iako ove vjerske skupine ne predstavljaju problem u slučaju odraslih osoba koje prihvaćaju njihova učenja, do problema dolazi kada se djeci, zbog religijskih razloga, onemogućuje pristup inače dostupnim medicinskim tretmanima. U prvom slučaju (Kršćanska znanost) religija potiče liječenje tjelesnih i umnih bolesti (samo) pomoću molitve (jedina iznimka su prijelomi kosti, kada se dozvoljava kratka intervencija liječnika, a nakon toga se liječenje nastavlja molitvom). Vjernici, dakle, kao ni njihova djeca, ne koriste liječničke usluge - pozivaju se na tekstove iz Biblije (posebice Novi zavjet) te navode kako Isus nije bolesne i slabe slao liječniku, već ih je liječio vjerom i riječju Božjom. Prema tome, samo Bog liječi, i samo se molitvom može otkloniti bolest (Gottschalk 1973, Fraser 1995).

Navest ćemo samo nekoliko problematičnih primjera: (i) 1987. godine Ashley King umrla je u svojoj 12. godini zbog tumora na desnoj nozi. Iako je mjesecima imala jasne zdravstvene probleme, roditelji je nisu vodili liječniku, a kad je, zahvaljujući reakciji nadležne institucije, nakratko oduzeta roditeljima i smještena u bolnicu, liječnik je zaključio da joj se više ne može pomoći, iako su postojale jako dobre šanse da je se spasi da se tumor počeo liječiti ranije. Također je preporučio da se djevojci amputira noga kako bi joj se umanjili bolovi prije nego što umre, ali njezini roditelji su je maknuli iz bolnice i smjestiti u religijsku ustanovu gdje je i umrla u strašnim bolovima, budući da joj noga nije bila amputirana, a nisu joj dani ni lijekovi protiv bolova jer su roditelji smatrali da sve probleme treba rješavati molitvom. Optuženi su za zlostavljanje djeteta i osuđeni na 3 godine uvjetnog zatvora. (ii) 1986. godine Robyn Twitchell, dijete od samo 2 godine, umro je zbog blokade crijeva koja se lako mogla ukloniti jednostavnim kirurškim zahvatom. Njegovi roditelji su osuđeni, ali je presuda poništena zbog žalbe 1993. godine. (iii) U isto vrijeme kad i Robyn, od dijabetesa je umrla i Amy Hermanson, sedmogodišnja djevojčica čiji su roditelji znali 
za njenu bolest, ali nisu zatražili medicinsku pomoć. I oni su prvotno osuđeni, a onda oslobođeni odlukom Vrhovnog suda Floride 1992. godine (Fraser 1995, Ontario Consultants on Religious Tolerance 2005, Peters 2007).

Jehovini svjedoci, s druge strane, načelno prihvaćaju suvremenu medicinsku praksu, ali ne i transfuziju krvi, budući da vjeruju kako odrasla osoba koja svojevoljno primi transfuziju čini veliki grijeh i time ugrožava svoj vječni život. Neke manje skupine unutar ove religije smatraju da se vječni život ugrožava i djeci kad im se daje transfuzija krvi, iako djeca sama nisu sposobna odlučivati o takvim pitanjima, no većina ipak smatra da se za grijeh treba raditi o odrasloj osobi. Kako bilo, Jehovini svjedoci rijetko ili gotovo nikad ne pristaju da se njihovoj djeci izvrši transfuzija krvi, čime se njihov život često ugrožava tako da su mjerodavne institucije ponekad prisiljene reagirati, iako sudovi često njihovu reakciju opisuju kao neopravdanu (Huggins 2005, Guichon i Mitchell 2006).

Dvije su stvari zajedničke u (gotovo) svim slučajevima; roditelji bolesnog djeteta su znali za njegovo teško zdravstveno stanje, ali iz religijskih razloga (ne zbog nemara) nisu mu pružili potrebnu medicinsku zaštitu. Kod posljednja dva primjera prisutan je još jedan bitan element; u oba su slučaja roditelji kasnije, odlukom Vrhovnog suda, oslobođeni, a optužbe protiv njih su poništene. Nesigurnost sudova upućuje na nejasnost relevantnih zakona - Vrhovni je sud poništio presude zato što je procijenio da nisu u skladu s Ustavom, točnije s Prvim amandmanom koji osuđuje svako djelovanje koje ograničava slobodno prakticiranje neke religije. Ova nesigurnost koju sudovi pokazuju upućuje na nedovršenost rasprave koja se još uvijek odvija, i u kojoj još nije jasno kako se pravni sustav treba postaviti prema važnim pitanjima. U nastavku ovog rada dajemo pregled relevantnih liberalnih pozicija koje odgovaraju na ovo pitanje.

\section{Moguća liberalna rješenja}

U središnjem dijelu prikazat ćemo četiri moguća rješenja na gore postavljeni problem - ona predstavljaju različite pozicije u širem području političke filozofije liberalizma. Sve pozicije na određeni, iako često bitno različit način, pretpostavljaju da su pojedinci nosioci nekih neotuđivih prava, te velik dio rasprave posvećuju objašnjavanju odnosa pojedinca i države, što je jedna od glavnih značajki liberalizma. One se, međutim, bitno razlikuju, kako u svojoj osnovi, tako i u konkretnim rješenjima koja nude na problem roditelja koji iz religijskih razloga lišavaju dijete dostupne medicinske njege.

Ove se pozicije također mogu gledati kao rješenja jednog drugog pitanja: već smo ranije napomenuli kako u uvjetima religijskog i moralnog pluralizma dolazi do neslaganja između razložnih doktrina, te se zajedničko zakonodavstvo suočava s problemom 
opravdanja zakona koji direktno krše neku od fundamentalnih vrijednosti jedne od (religijskih) grupa (a nužno će kršiti nečije fundamentalne vrijednosti, budući da postoje potpuno suprotne, ali i dalje razložne doktrine). Sve pozicije koje ćemo ovdje prikazati predstavljaju rješenje za ovaj problem, a time i za glavni problem koji se provlači kroz ovaj rad - u kojim slučajevima država može intervenirati i ograničiti prava pojedinaca.

\section{(I) Liberalni arhipelag}

Prva od liberalnih pozicija koje prikazujemo u ovom radu zastupa ideju kako je benigno zanemarivanje najbolja strategija koju država može primijeniti u uvjetima religijskog i moralnog pluralizma. Pozicija poznata kao liberalni arhipelag (Kukathas 2003) tvrdi da država treba imati minimalnu ulogu, te da se gotovo sve ovlasti moraju prepustiti manjim lokalno-administrativnim jedinicama u kojima će obitavati pojedina religijska ili kulturna zajednica. Zajednice koje postoje unutar države međusobno će se tolerirati, ali se neće uplitati u tuđe poslove niti će pokušavati jedna drugoj nametnuti svoju koncepciju dobra. Benigno zanemarivanje omogućuje svakoj kulturnoj ili religijskoj zajednici da sama, bez uplitanja države, organizira vlastito unutarnje uređenje te kulturni i društveni život. Same zajednice ne moraju nužno biti liberalno uređene; bitno je jedino da njihovi članovi imaju pravo napustiti zajednicu kojom nisu zadovoljni i uključiti se u neku drugu. Ovakvo društvo Kukathas (2003) uspoređuje s arhipelagom u kojem svaka zajednica predstavlja jedan od otočića, dok ih sve povezuje more tolerancije.

Neki sumnjaju u liberalnost ove pozicije, budući da dopušta i opravdava postojanje neliberalnih zajednica u kojima se krše neka od temeljnih ljudskih prava. Odgovor je u prioritetu koji Kukathas, za razliku od većine drugih liberala (koji počinju od autonomije), daje slobodi udruživanja - nema ništa problematično ako ljudi ne žele živjeti u egalitarnom liberalnom društvu, već se svojevoljno udruže u neki njegov neliberalni ili neegalitarni oblik. Bitno je jedino da se pojedincima ostavi zajamčeno pravo da u bilo kojem trenutku napuste svoju zajednicu ako njome nisu zadovoljni.

Kukathas se eksplicitno ne izjašnjava glede pitanja roditelja koji, iz religijskih uvjerenja, odbijaju svom djetetu pružiti dostupnu medicinsku pomoć, ali obrađuje sličan primjer, u kojem roditelji djetetu ne žele pružiti dostupno i kvalitetno obrazovanje. Njegov je odgovor ovdje prilično radikalan: ne smijemo nametati vlastiti ideal dobrog života drugim zajednicama i, prema tome, ne smijemo se uplitati u kršenja onog što mi smatramo ljudskim pravima, kada se pojavljuje u drugim zajednicama (Kukathas 2003). Bitno je istaknuti kako i drugi sudionici u raspravi povlače analogiju između pristupa obrazovanju i pristupa zdravstvu. 
"Kukathas, sjetit ćete se, državi pripisuje vrlo ograničenu ulogu. Prema njemu, njezin je posao spriječiti konflikte među grupama, ali ne miješati se u njihove unutarnje stvari radi zaštite njihovih članova. On je, stoga, pripravan reći kako bi država trebala stajati po strani i pustiti roditelje da nekažnjeno tjelesno osakate svoju djecu i da oni ne bi smjeli podlijegati ikojoj kazni jer su prouzročili djetetovu smrt time što nisu potražili ili odobrili liječnički tretman koji bi mu spasio život”. (Barry 2001)

"Chandran Kukathas je naklonjeniji od mene prema zahtjevima kulturalnih skupina za nametanje unutarnjih ograničenja vlastitim pripadnicima, budući da misli kako liberalizam nije predan vrijednosti autonomije. Liberalna tolerancija, prema njegovu gledištu, podrazumijeva da se neliberalne skupine ostave na miru, a ne podrazumijeva da im država pomogne na bilo koji način - putem financiranja škola, jezičnih prava, prava na veto i sl. Prema ovom gledištu, liberali bi trebali uvažavati neliberalne skupine, dokle god one ne traže nikakvu podršku od šireg društva, i ne nastoje drugima nametnuti svoje vrijednosti”. (Kymlicka 1995)

Postoji čitav niz prigovora koji se upućuju poziciji liberalnog arhipelaga. Brian Barry (2001) smatra da Kukathas ne razlikuje pravo da se izađe iz zajednice i mogućnost da se to učini. Kada piše kako zajednice mogu biti neliberalne, te kako je jedino bitno da svojim članovima daju pravo da zajednicu napuste, ne podrazumijeva da zajednice moraju dati i mogućnosti da ih se napusti. Zamislimo neko radikalno neliberalno društvo u kojem žene ne smiju posjedovati imovinu ili novac, te im je zabranjeno školovanje - za zastupnike liberalnog arhipelaga ovo nije problematično društvo dok god svi njegovi članovi žele biti dio tog društva, odnosno dok im ono daje pravo da ga napuste kad god to požele. Međutim, spomenute žene mogu imati pravo, ali ne i mogućnosti da ga napuste; budući da ne posjeduju nikakav novac ili imovinu, kao i zbog nedostatka adekvatnog obrazovanja, ne mogu pronaći nikakav posao u drugim zajednicama; žene u ovom neliberalnom društvu, dakle, nemaju mogućnost (iako imaju pravo) da ga napuste. Ako im želimo dati mogućnosti da ga napuste, trebamo im osigurati i neka druga prava i mogućnosti (pravo na obrazovanje, na posjedovanje privatnog vlasništva i sl.), najčešće do te razine da to društvo, jednom kad ženama i svim drugim društveno marginaliziranim skupinama zajamči ovakva prava, više neće biti neliberalno. Ista se argumentacija može primijeniti na slučaj djece i uzdržavanih osoba - budući da nisu u mogućnosti izaći iz zajednice, potrebno im je osigurati niz drugih prava koja bi im to omogućila. Pravo na adekvatnu zdravstvenu zaštitu svakako spada među prava nužna za ostvarenje mogućnosti izlaska iz zajednice. 


\section{(II) Liberalni multikulturalizam}

Multikulturalizam danas označava čitav niz različitih politika, a mi se u ovom prikazu bavimo liberalnom teorijom manjinskih prava koju iznosi kanadski filozof Will Kymlicka. Treba uzeti u obzir kako se Kymlicka prvenstveno bavi stvaranjem teorije koja će riješiti probleme etničkog i kulturnog, a ne religijskog i moralnog pluralizma, ali unatoč tome ne smije se zanemariti njegov doprinos ovoj raspravi. Za razliku od Kukathasa, Kymlicka $(1995,2001)$ smatra kako pojedine religijske zajednice trebaju imati posebna pozitivna, a ne negativna prava ${ }^{8}$. Drugim riječima, on smatra kako se država smije uplitati u neliberalne zajednice koje na jasan način krše ljudska prava (suprotno od Kukathasa), ali isto tako smatra da te zajednice imaju prava na posebnu zaštitu države, bilo u pravnom ili financijskom smislu (opet za razliku od Kukathasa, koji smatra da se država ne smije uplitati ni ograničavajući, ni pomažući manjinske zajednice) (Kukathas 2003, 2008).

Primijenimo li ranije iznesene teze liberalnog multikulturalizma na pitanje roditelja koji ograničavaju svojoj djeci pristup medicinskim tretmanima na osnovi religijskih razloga, pogotovo kada se radi o odbijanju tretmana koji mogu spasiti djetetov život, liberalni multikulturalisti prepoznali bi kako se radi o kršenju prava i interesa djeteta, osudili roditelje i smatrali kako država ima pravo (i dužnost) da zaštiti djecu (Parekh, 2014). Međutim, liberalna multikulturalna teorija ovdje nije gotova: država ima i dužnost izaći ususret religijskim zajednicama i pokušati pronaći kompromis kojim bi se sačuvale njihove vrijednost $s$ jedne, a zaštitila prava pojedinaca s druge strane. Na primjeru Jehovinih svjedoka koji ne žele da njihovo dijete primi transfuziju krvi, država ima dužnost zaštititi život djeteta, ali i dužnost uvažavati religijske posebnosti Jehovinih svjedoka i uložiti posebna sredstva kako bi se izašlo ususret njihovim zahtjevima. Krv koju se daje transfuzijama moguće je, u određenim slučajevima, zamijeniti umjetnim supstitutom čiju će transfuziju Jehovini svjedoci prihvatiti (Findley i Redstone 1982, Corthen i dr. 2002, Sloan i Ballen 2008). Kymlicka i drugi zastupnici liberalnog multikulturalizma smatraju kako je dužnost države da ulaže dodatna sredstva kako bi proizvodila i dodatno razvijala supstitute hemoglobina i drugih krvnih sastojaka, te na taj način omogućila Jehovinim svjedocima (i njihovoj djeci) da prežive zahvaljujući supstituciji krvi koja se ne bi kosila s njihovim religijskim pravilima. Liberalni multikulturalizam smatra kako je različitost kulturnih i religijskih doktrina nešto vrijedno, te da se zato država treba zalagati kako bi je osigurala, tj. kako bi pomagala manjinskim grupama.

8 Prava u negativnom smislu okrenuta su prema zaštiti pojedinca od utjecaja drugih, odnosno od utjecaja države. Prava u pozitivnom smislu zahvaćaju i mogućnosti pojedinaca da realiziraju svoje koncepcije dobrog života, odnosno da djeluju i odlučuju o javnim pitanjima (Berlin 1969). 
Glavni prigovor Kymlicki upućuje Brian Barry koji ističe kako ovakav liberalni multikulturalizam ne uočava bitnu razliku između potreba i preferencija. Sasvim su različite teze kako država treba djelovati da bi zadovoljila potrebe, odnosno kako treba djelovati da bi zadovoljila preferencije pripadnika religijskih manjina. Religijske dužnosti Barry karakterizira kao preferencije, ne kao stvarne potrebe pojedinaca (Barry 2001). Potrebe pojedinca Barry ne svodi samo na temeljne fiziološke potrebe za hranom, vodom ili čistim okolišem, već uključuje i potrebe višeg reda (Maslow 1943), međutim, odlučno odbacuje mogućnost da se supstantivne religijske dužnosti karakteriziraju kao potrebe. Primjerice, ako neki musliman ima religijsku dužnost barem jednom u životu posjetiti Meccu, ili ako neki katolik ima religijsku dužnost petkom ne jesti meso, riječ je o preferencijama, a ne potrebama pojedinaca. Država nema dužnost zadovoljavati religijske preferencije pojedinaca. Naravno, država ih ne smije ni zabranjivati (osim ako štete drugim pojedincima), ali nema dužnost ulagati javna sredstva niti prilagođavati zakone i javne politike kako bi omogućila njihovo zadovoljenje. Ova se Barryjeva kritika može primijeniti i na Kymlickino rješenje našeg središnjeg problema; država nema dužnost da izdvaja dodatna, možda i iznimno velika sredstva za pronalaženje i proizvodnju supstituta hemoglobina i drugih krvnih sastojaka kako bi zadovoljila jednu od religijskih preferencija. To ne znači da se takva istraživanja ne smiju provoditi, ali ih trebaju financirati sami religiozni pojedinci, a ne država. Isto tako, religiozni bi roditelji, ili pak njihove religijske organizacije i organizacije civilnog društva, trebale osiguravati supstitute krvi za djecu za koju ne žele da prime transfuziju krvi. Ako to nisu u mogućnosti priskrbiti, država ima pravo i dužnost intervenirati i osigurati da djeca dobiju transfuziju krvi, a nema dužnost ulagati javna sredstva u nabavu takvih supstituta.

\section{(III) Egalitarni liberalizam}

Suprotno ranije prikazanim pozicijama, egalitarni liberalizam smatra kako je moguće objektivno evaluirati vrijednost svih kultura i religija. Egalitarni liberalizam tako nastupa protiv multikulturalizma tvrdeći kako se država prema svima treba odnositi jednako (egalitarizam) i kako ne smije biti manjina koje su na osnovi svojih preferencija privilegirane u neki slučajevima. Ako neki zakon vrijedi za sve, onda treba vrijediti i za pripadnike neke religijske ili kulturne manjine koja se $s$ njime ne slaže. Ako zakon ne vrijedi za neke, onda ne treba vrijediti ni za koga9 (Barry

9 Egalitarni liberalizam ne polazi od ideje da ne smije biti izuzetaka u pravilima koja vrijede za sve. Izuzeci su nužni za normalno funkcioniranje društva: primjerice, izuzeće vozila hitne pomoći prilikom intervencije od pravila da se mora zaustaviti na semaforu kada je upaljeno crveno svijetlo za egalitarne liberale nije problematično, budući da se lako može opravdati. Riječ je o funkcionalnom izuzetku, a ne izuzetku utemeljenom na kulturi ili religiji. Kada bismo izuzeće od prometnih pravila dali nekoj etničkoj ili religijskoj grupi, ne bismo bili u mogućnosti kvalitetno opravdati to izuzeće (Barry 2001). 
2001, 2005). Zašto bismo, pita se Barry, roditeljima koji su Jehovini svjedoci ili članovi Kršćanske znanosti tolerirali što nisu liječili svoje dijete koje je od neke, inače za modernu medicinu bezazlene bolesti, preminulo, a istu stvar ne bismo trebali tolerirati roditeljima koji su ateisti ili pripadnici neke druge religije? Ako je zakon koji štiti prava i interese djeteta opravdan, onda se mora jednako primjenjivati na sve; ako nije opravdan, onda ga se nitko ne treba pridržavati.

Za razliku od Kymlicke (1995), Barry (2001) smatra kako država nema nikakve obaveze prema pripadnicima manjinskih kulturnih ili religijskih grupa; njihovi kulturni i religijski zahtjevi spadaju u preferencije, a ne u potrebe, i zbog toga njihovo ispunjenje ostaje na samim pojedincima, a ne na državi. Stajalište egalitarnog liberalizma jest da pravednost zahtijeva jednaka prava i šanse, ali ne nužno i jednake ishode za sve skupine. Ako netko razvija skupe i teško dostižne preferencije bit će mu puno teže zadovoljiti ih nego nekome tko preferira jeftine i lako dostupne stvari. Uloga države nije da osigura jednako zadovoljenje preferencija za sve građane (egalitarni liberalizam ne zahvaća ovu radikalnu verziju jednakosti), nego da svima osigura zadovoljenje osnovnih potreba, te svima pruži jednake mogućnosti.

Egalitarni liberalizam nije teorija koja se mora prilagođavati kulturnim razlikama, ona ima svoj kriterij koji čine liberalna načela i kroz njih procjenjuje pravednost grupnih ili političkih praksi. $\mathrm{Na}$ osnovi ovih kriterija neke se kulture ili religije može opravdano osuđivati, čak i prezirati (Barry 2001), a među njima bile bi i one koje se zalažu za uskraćivanje medicinske pomoći ili određenih medicinskih tretmana teško oboljeloj djeci. Egalitarni liberali ovakva odbijanja potrebnih medicinskih tretmana opisuju i osuđuju kao "zadnju budalaštinu ili zvjerstvo počinjeno negdje u svijetu, koje netko opravdava u ime multikulturalizma” (Barry 2001).

Egalitarnom liberalizmu često se prigovara kako je riječ o političkoj poziciji koja je slijepa na razlike, no njegovi će zastupnici spremno odgovoriti kako su uistinu slijepi na nerelevantne razlike, odnosno uočavaju relevantne razlike u sposobnostima i potrebama, no religijski svjetonazori to ne predstavljaju. Ovoj se poziciji, međutim, može prigovoriti da nedovoljno uočava značaj koji nečija duboka moralna ili religijska vjerovanja mogu imati u procesu prihvaćanja legitimnosti zakona i javnih politika koje reguliraju život u političkoj zajednici. Duboka moralna i religijska vjerovanja mogu pojedincima biti toliko važna da će radije odbaciti vrijednosti i zahtjeve demokratskog društva (koje ih svojim odlukama ograničava) nego se odreći svojih religijskih uvjerenja i praksi (Talisse 2009a, 2009b). Egalitarnom liberalizmu prigovara se da je sektarijanski, tako da promiče određenu liberalnu ideju dobrog života i prisiljava građane koji prihvaćaju druge razložne doktrine da se prilagode, ne izlazeći im nimalo ususret. Kompromisi i umjereno udovoljavanje religijskim zahtjevima pojedinaca i grupa omogućuje im da se lakše integriraju u društvo, a da pri tome zadrže vlastite religijske i moralne vrijednosti. 


\section{(IV) Liberalni feminizam}

Svi u ovom radu ranije spominjani teoretičari i pozicije koje zastupaju pretpostavljaju da roditelji imaju određena prava u oblikovanju života svoje djece, poput odabira obrazovanja, mjesta stanovanja, prehrane, odgojnih metoda i slično, iako se međusobno ne slažu oko sadržaja ili stupnja tih prava. Drugim riječima, ranije prikazane pozicije pretpostavljaju da postoje određena roditeljska prava koja mogu spriječiti državu da legitimno intervenira u korist djeteta. Ove se pozicije ne slažu ni oko slučajeva u kojima država smije legitimno reagirati, ali sve pretpostavljaju da je država ta koja treba opravdati svoje uplitanje u slučajevima kršenja roditeljskih prava. Teret dokaza je na državi, koja mora opravdati svoje uplitanje u početno stanje, u kojem roditelji imaju pravo odabira kako će odgajati i liječiti svoju djecu. Liberalni feminizam dovodi u pitanje postojanje roditeljskih prava te argumentira kako država treba imati ovlasti da intervenira svaki put kad se šteti djetetu ili krše njegova prava (Dwyer 1994, Okin 1989, 1999).

Zastupnici roditeljskih prava svoj prilog argumentiraju na tri načina; pozivaju se (i) na interese djeteta i tvrde kako je u njegovu interesu da odrasta u okruženju onih koji ga najbolje poznaju i najviše brinu o njemu, zatim (ii) na interese roditelja koji žele odgajati svoju djecu u privatnosti i u skladu sa svojim uvjerenjima, te (iii) na interese društva koje teži pluralizmu i slobodnoj obitelji kao osnovnoj građevnoj jedinici demokratske kulture. Liberalni feministi odbacuju ove argumente, smatrajući kako roditelji smiju imati samo privilegiju, ali ne i pravo, da brinu o (vlastitoj) djeci (Okin 1989, Hubin 2013). Oni bi, prema ovoj teoriji, imali odobrenje da se brinu o djeci, odgajaju ih ili biraju tretmane kojima će ih se liječiti, ali iz te privilegije ne bi proizlazilo nikakvo pravo na koje bi se mogli pozivati kad bi država odlučila intervenirati u ove procese. Liberalni feminizam, pogotovo njegova verzija izražena kroz djela Okin $(1989,1999)$ i Satz (2009), teži promjeni paradigme prema kojoj početna pozicija nije utemeljena u roditeljskom pravu da određuju sve aspekte života djeteta, nego u pravu i dužnosti države da skrbi o djeci, odnosno o svim pojedincima koji nisu u mogućnosti činiti to za sebe.

Liberalni feminizam ne pretpostavlja odustajanje od obitelji kao temeljne jedinice reprodukcije društva, niti se zalaže da država preuzme brigu o zdravlju djece. Isto tako, ova pozicija ne mora nužno postaviti jako stroge kriterije brige o djetetu i kažnjavati roditelje koji ih ne zadovoljavaju. Okin smatra da se, u dobro uređenim obiteljima koje prihvaćaju liberalne vrijednosti, ovom reformom ne bi gotovo ništa promijenilo - prepuštanje brige od djetetu njegovim roditeljima uglavnom je najbolji način kako država može skrbiti za njegovo blagostanje i štititi njegova prava. Reforma koju predlažu liberalni feministi značajno bi utjecala samo na neliberalne obitelji u kojima dominiraju radikalni religijski stavovi i koje, često upravo na osnovi religije, 
javno osuđuju svako uplitanje države u pitanja brige o zdravlju djeteta. Naglasak je na promjeni paradigme; djeca nisu vlasništvo roditelja i oni se ne mogu pozivati na pravo da odlučuju o životima svoje djece.

Unatoč početnoj zanimljivosti teorije, moramo uzeti u obzir da teze koje liberalni feministi iznose nisu u skladu s intuicijama većine ljudi. To, naravno, ne znači da je teorija pogrešna, ali upućuje da moramo malo bolje razmotriti prigovore koji joj se mogu uputiti. $U$ ovom slučaju to su svi prigovori koje možemo uputiti i egalitarnom liberalizmu Briana Barryja (koji također zastupa nešto veće ovlasti države), ali i niz novih. Kymlicka argumentira da ovo rješenje ne uviđa vrijednost kulturalne i religijske različitosti u društvu, te od države ne zahtijeva da pomaže manjinske skupine koje se nalaze u neprivilegiranom položaju u odnosu na većinu, kršeći tako manjinska prava (Kymlicka 1992, 1999). Kukathas, koji zastupa poziciju gotovo dijametralno suprotnu liberalnom feminizmu, tvrdio bi kako ova pozicija ograničava slobodu pojedinaca, točnije ograničava uvjete pod kojima se mogu slobodno udruživati i autonomno odlučivati pod kakvim zakonima i pravilima žele živjeti (Kukathas 1995).

\section{Zaključak}

Rasprava koju smo prikazali u ovom radu još uvijek je aktualna i ne postoji akademski konsenzus oko njezina rješenja - prema tome, bitno je istaknuti kako je ovo diskutabilna tema u kojoj nalazimo više razložnih, plauzibilnih pozicija, te joj zbog toga ne smijemo pristupati neoprezno i dogmatično. Vjerujemo da će integrativna bioetika pružiti znatan doprinos rješenju ovog i sličnih pitanja.

Rubne pozicije, poput liberalnog arhipelaga Chandrana Kukathasa i liberalnog feminizma Susan Moller Okin, predstavljaju zanimljive i čvrste teorijske modele pomoću kojih se mogu testirati naše intuicije vezane uz temeljne vrijednosti koje obilježavaju liberalna društva, no njihova realizacija i implementacija nije ostvariva u političkoj praksi. Glavne suprotstavljene teorije danas ujedno su i one koje najviše utječu na zakonodavstvo, kao i na druge povezane medicinske prakse; liberalni multikulturalizam Willa Kymlicke i egalitarni liberalizam Briana Barryja. Njihova privlačnost (pogotovo u pitanju njihove primjene na rješavanje javnih problema) velikim dijelom ovisi i o široj ekonomskoj situaciji, budući da neke od mjera koje liberalni multikulturalizam uvodi mogu biti dosta skupe i opterećujuće za državni proračun, kao i o svjetonazorskoj i geopolitičkoj situaciji, odnosno načinu kako se u društvu percipiraju neke kulturne ili religijske manjine. Budući da obje teorije polaze od zaštite temeljnih prava i interesa djece, a razlikuju se oko zahtjeva koje postavljaju na javni zdravstveni sustav (tj. na državu), smisleno je zaključiti kako odluku oko primjene jednog ili drugog modela u većini slučajeva možemo donijeti 
pravičnom i dobro strukturiranom demokratskom deliberacijom. Slučajevi roditelja koji uskraćuju svojoj djeci dostupnu medicinsku skrb iz religijskih razloga izrazito su raznoliki i postoji opravdana bojazan kako se neki od njih neće adekvatno riješiti ako se unaprijed izabere i na sve jednako primijeni samo jedan teorijski pristup. Također, okolnosti i uvjeti u kojima dolazi do ovih slučajeva uvelike variraju, tako da će i moguća rješenja varirati među različitim situacijama. Jednom kada su temeljna prava i interesi djece zaštićeni ne izgleda pogrešno dio odlučivanja prepustiti dobro strukturiranoj demokratskoj deliberaciji ${ }^{10}$. Argumenti prikazani u ovom radu tako zadržavaju svoju korisnost kao razlozi za ili protiv primjene svake od prikazanih pozicija u konkretnim slučajevima uskraćivanja zdravstvene skrbi iz religijskih razloga.

\section{Literatura}

1. Barry, B. (2001) Kultura i jednakost: Egalitarna kritika multikulturalizma, Zagreb: Naklada Jesenski i Turk.

2. Barry, B. (2005) Why Social Justice Matters. Cambridge: Polity.

3. Berlin, I. (1969) Four Essays on Liberty. London: Oxford University Press.

4. Cothren, C. i dr. (2002) Blood Substitute and Erythropoietin Therapy in a Severely Injured Jehovah's Witness. The New England Journal of Medicine. Vol. 346. (1097-1098)

5. Daniels, N. (2008) Just Health: Meeting Health Needs Fairly. New York: Cambridge University Press

6. Dwyer, J. G. (1994) “Parents' Religion and Children's Welfare: Debunking the Doctrine of Parents' Rights", U: College of William \& Mary Law School Faculty Publications, Vol. 168.

7. Findley L. J. i Redstone, P. M. (1982) Blood transfusion in adult Jehovah's Witnesses. A case study of one congregation. Arch Intern Med, Vol. 142 (606-607)

8. Fraser, C. (1995) Suffering Children and the Christian Science Church. The Atlantic Monthly, Vol. 264, No. 4 (105-120)

9. Gottschalk, S. (1973) The Emergence of Christian Science in American Religious Life. London: University of California Press.

10. Guichon, J. i Mitchell, I. (2006) Paediatr Child Health. Vol. 11, No. 10 (655-658)

11. Hubin, D. C. (2013) Human reproductive interests: puzzles at the periphery of the property paradigm. U: Paul, E. F., Miller, F. D. i Paul, J. (2013) New Essays in Political and Social Philosophy. Cambridge: Cambridge University Press.

12. Huggins, C. E. (2005) Childbirth Death Risk High in Jehovah's Witnesses. American Journal of Obstetrics and Gynecology, Vol. 185 (893-895)

13. Jurić, H. (2011). Riječka deklaracija o budućnosti bioetike. U: 10. lošinjski dani bioetike. Mali Lošinj, 15. - 18. svinja 2011. Zagreb: Hrvatsko filozofsko društvo.

14. Kuenssberg, L. (2011) “State multiculturalism has failed, says D. Cameron”, BBC News. 5. veljače. Dostupno na: http://www.bbc.co.uk/news/uk-politics-12371994 [Pristupljeno: 29. svibanj 2011.]

15. Kukathas, C. (1992) Are There Any Cultural Rights?. Political Theory, Vol. 20 (105-139)

10 Za više informacija o ovoj strategiji vidi knjigu Normana Danielsa Just Health: Meeting Health Needs Fairly. Bitno je istaknuti kako Daniels ne preuzima čisti proceduralisitički pristup u kojem legitimnost odluke proizlazi iz činjenice da je podupire većina građana, već kombinira Rawlsov liberalni kriterij političke legitimnosti s praksama deliberativne demokracije. 
16. Kukathas, C. (2003) The Liberal Archipelago: A Theory of Diversity and Freedom, Oxford: Oxford University Press.

17. Kukathas, C. (2008) Anarcho-multiculturalism: the pure theory of liberalism. U: Levey, G. B. (Ur.) Political Theory and Australian Multiculturalism. New York: Berghahn Books (29-43)

18. Kymlicka, W. (1992) The Rights of Minority Cultures: Reply to Kukathas. Political Theory Vol. 20, No. 1 (140-146)

19. Kymlicka, W. (1995) Multikulturalno gradanstvo: Liberalna teorija manjinskih prava, Zagreb: Jesenski i Turk.

20. Kymlicka, W. (1999) Liberal Complacencies. U: Cohen, J. i Howard, M. (1999) Is Multiculturalism Bad for Women? New Jersey: Princeton University Press

21. Kymlicka, W. (2001) Politics in the Vernacular: Nationalism, Multiculturalism, and Citizenship. Oxford: Oxford University Press.

22. Maslow, A. H. (1943) A theory of human motivation. Psychological Review, Vol 50, No. 4 (370-396)

23. Mill, J. S. (1963) Collected Works of John Stuart Mill, J. M. Robson (ed.), Toronto: University of Toronto Press.

24. Okin, S. M. (1989) Justice, Gender and the Family. Basic Books: New York.

25. Okin, S. M. (1999) Is Multiculturalism Bad for Women? U: Cohen, J. i Howard, M. (1999) Is Multiculturalism Bad for Women? New Jersey: Princeton University Press

26. Ontario Consultants on Religious Tolerance (2005) Two Christian groups that oppose medical care [Online] Dostupno na: http://www.religioustolerance.org/medical2.htm [Pristupljeno: 1. lipanj 2011]

27. Parekh, B. (2014) Cultural Defense and the Criminal Law. U: Kymlicka, W., Lernestedt, C. i Matravers, M. (2014) Criminal Law and Cultural Diversity. New York: Oxford University Press.

28. Peters, S. F. (2007) When Prayer Fails: Faith Healing, Children, and the Law. New York: Oxford University Press.

29. Rawls, J. (1971) A Theory of Justice. Cambridge, Mass: The Belknap Press of Harvard University Press.

30. Rawls, J. (1993) Political Liberalism. New York: Columbia University Press.

31. Rawls, J. (1999) The law of peoples with 'The idea of public reason revisited'. Cambridge: Harvard University Press.

32. Satz, D. (2009) Toward a Humanist Justice. U: Satz, D. i Reich, R. (2009) Toward a Humanist Justice: The Political Philosophy of Susan Moller Okin. New York: Oxford University Press

33. Sloan, J. M. i Ballen, N. (2008) SCT in Jehovah's Witnesses: the bloodless transplant. Bone Marrow Transplantation, Vol. 41 (837-844)

34. Škrobonja, A., Muzur, A. i Rotschild. V. (2003) Povijest medicine za praktičare. Rijeka: Adamić.

35. Taliesse, R. (2009a) Democracy and Moral Conflict. New York: Cambridge University Press.

36. Talisse, R. (2009b) Folk Epistemology and the Justification of Democracy, U: Tinnevelt, R. i Geenens, R (Ur.) (2009) Does Truth Matter? Democracy and Public Space. Springer, Dordrecht. 


\section{Liberal Responses to the Problem of Denying Medical Care to Children and Juveniles for Religious Reasons}

\section{SUMMARY}

Medical experts, both in Croatia and in the world, are facing nowadays an increasing number of cases where the parents refuse, because of certain religious reasons, medical care and certain medical treatments for their children, even though those treatments could preserve the children's health or even save their lives. The parents are convinced that they are acting with good intentions and in child's favour, which leads to certain problems regarding the regulation of these cases, as well as to disagreements regarding the rights of parents and their children, or the legitimacy of state interventions in this sphere. This paper puts forward four possible liberal solutions to the above described problem (liberal archipelago, liberal multiculturalism, liberal egalitarianism and liberal feminism), specifies the scope of legitimate interventions by the state that these theories allow, and reviews the advantages of each position, as well as the most important objections directed toward each.

Keywords: liberal archipelago, liberal multiculturalism, liberal egalitarianism, liberal feminism. 